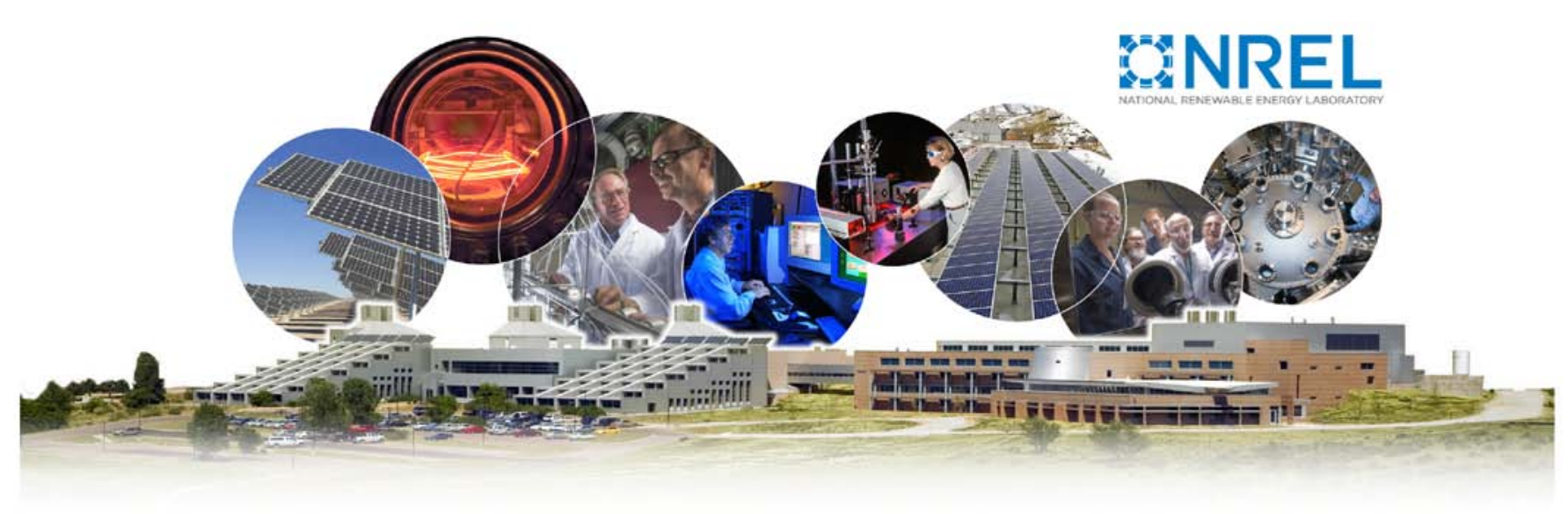

\title{
Measurements and Characterization: Cell and Module Performance
}

Scope. The Measurements and Characterization (M\&C) Division at the National Renewable Energy Laboratory and the National Center for Photovoltaics provides characterization support, collaborative research, and the development of new measurement techniques and diagnostics to advance the photovoltaic (PV) generation of energy. M\&C researchers use stateof-the-art characterization tools to solve problems in all phases of material and device development. The result of these efforts is an increased understanding that drives improvements in the performance, reliability, price, and manufacturability of PV materials, devices, and systems.

The M\&C project consists of four closely integrated core competency groups:

- $\quad$ Analytical Microscopy

- $\quad$ Electro-Optical Characterization

- Surface Analysis

- $\quad$ Cell and Module Performance

Each group uses a wide array of state-of-the-art measurements and characterization techniques and has highly trained staff with a combined total of more than 500 years of experience in PV materials and device characterization. This extensive PV experience base, coupled with the breadth of our capabilities and highly integrated approach, sets us apart from other organizations throughout the world. The M\&C project has a long history of working with the PV community to solve material, device, manufacturing, packaging, and reliability issues. We strive to develop a solid scientific foundation to help our customers advance their manufacturing process development, research, and reliability R\&D to a higher level.

We enthusiastically welcome industry, manufacturing, university, and government enterprises to collaborate with us. We are motivated to share our expertise and knowledge base and to collaborate on research, problem-solving, and commercial product development. For more information, please see our Web site at www.nrel.gov/pv/measurements/.

Core Competencies and Capabilities. The Cell and Module Performance Group is the premier U.S. Department of Energy research laboratory for testing performance of commercial, developmental, and research PV devices. We are one of only two laboratories in the world to hold an International Organization for Standardization (ISO) 17025 accreditation for primary reference cell and secondary module calibration, in addition to accreditation for secondary reference cell calibration under American Society for Testing Materials (ASTM), and International Electrotechnical Commission (IEC) standards. We are one of only four laboratories in the world certified in accordance with the IEC standard for calibrating terrestrial primary reference PV cells. We test all types of devices from around the world, putting all PV performance measurement "on the same page." A brief summary of our capabilities is listed below.

- $\quad$ Current versus Voltage (I-V) measurements

- Simulated cell I-V

- Simulated module I-V

- Outdoor module I-V

- $\quad$ Spectral responsivity (SR/QE)

- Reference cell calibrations

- American Association for Laboratory Accreditation (A2LA) ISO 17025 accredited

\section{Contact/Web}

- $\quad$ Keith Emery, Keith.Emery@nrel.gov, 303-384-6632

- Web: www.nrel.gov/pv/measurements/device_performance.html 